\title{
A Cross Sectional Study on Awareness Level of Onychomycosis Patients
}

\begin{abstract}
Keywords: Awareness; Onychomycosis
Abstract

Onychomycosis is a common nail problem in our country. Diabetic patients are more prone to develop onychomycosis. Various types of fungi are the causative agents of nail infections. This study was designed to assess awareness level of onychomycosis patients. Awareness leve was measured by pre-defined score like poor ( $<50 \%$ of the total score) moderate $(50 \%-70 \%$ of the total score) and good $(>70 \%$ of the total score). Respondent who meet all the inclusion and exclusion criteria were taken for fulfill questioners of preformed data collection sheet. Descriptive as well as inferential statistics were used to present data. Mean $\pm S D$ age of respondents was $25.31 \pm 5.10$ years. More than hal (55\%) of the respondents completed primary level education. Most of the respondents were housewife. Mean $\pm S D$ income of respondents was $10958.71 \pm 4282.89$ BDT per month. Majority of respondents were Muslim (86\%). Distribution of nuclear and joint family were $68 \%$ and $32 \%$. Most of the respondents (82.6\%) had good awareness on clinical presentation of onychomycosis. As like clinical presentation awareness on seek medical care was also good among $83.5 \%$ respondents. No statistical significant association was found between occupation family type, education, income and awareness on onychomycosis. It is concluded from the study that overall awareness level on different area of onychomycosis among patients was quite acceptable. Large scale study will explore more accurate and precise result.
\end{abstract}

\section{Introduction}

Onychomycosis is a progressive, recurring fungal infection that begins in the nail bed and progresses to the nail plate [1]. Fungal nail infections increase the susceptibility of patients to other serious complications. In diabetic patients onychomycosis can open the door to secondary bacterial infections promoting foot ulcers and gangrene [2]. Onychomycosis can also trigger recurrent cellulitis and thrombophlebitis [3]. In addition to these significant health problems the substantial psychosocial consequences of onychomycosis alone justify serious management. Patients with diabetes are particularly susceptible to fungal nail infections because they often experience impaired sensation lack of pain sensation can make them less aware of trauma to their feet such as nail changes that develop during onychomycosis [4]. Onychomycosis is common in Bangladesh but significant study is scarce. Onychomycosis which is a common fungal infection of nail is caused by dermatophytes yeast and mould. It constitutes an important public health problem because of its rising prevalence and under-diagnosis especially in developing countries. Assessment of awareness level is considered an important step to prevent or minimize of a disease and its complication.

\section{Methodology}

This study was a cross-sectional study. About 109 patients clinically diagnosed as onychomycosis and patients of both sexes and all ages were included in the study. Sample was conveniently selected. Three categories were defined on the basis of the score obtained by

\section{Journal of}

\section{Clinical \& Investigative} Dermatology

\section{Nahida Islam*}

Department of Dermatology and Venereology, Community Based Medical College, Bangladesh

\section{*Address for Correspondence}

Nahida Islam, Department of Dermatology and Venereology, Community Based Medical College, Bangladesh, E-mail: cnbuhs2013@gmail.com

\section{Submission: 06 September, 2017 \\ Accepted: 25 September, 2017 \\ Published: 03 October, 2017}

Copyright: $\odot 2017$ Islam N. This is an open access article distributed unde the Creative Commons Attribution License, which permits unrestricted use, distribution, and reproduction in any medium, provided the original work is properly cited.

each participant: poor ( $<50 \%$ of the total score) moderate $(50 \%-70 \%$ of the total score) and good ( $>70 \%$ of the total score) and it was predefined. Clinical presentation as like discoloration and disfigurement of nail as well as medical care were considered as piece of question. A questionnaire was developed containing both closed and open ended questions to obtain relevant information. All questions were designed, pretested, modified and resettled to obtain and record information easily. The purpose of the pre-test was to test the content, wording and expression the topical sequence of questions and duration of the interview and the reliability of some items. After pretest the individual questionnaire which were related for quantitative data collection were improved and reformed to ensure content coverage the reliability and validity of the study. All the respondents were interviewed about personal characteristics and their monthly income, family size, economical condition, educational information, housing conditions, living conditions. All of the information's were recorded in the respective places of the questionnaire. Data analysis was carried out with the aid of IBM Statistical Package for the Social Sciences (SPSS) version 21.00.

\section{Results}

The result of the study was presented in tabular and graphical form there by interpretation of the result in the chapter under the following headings. Three categories were defined on the basis of the score obtained by each participant: poor $(<50 \%$ of the total score) moderate (50\%-70\% of the total score) and good ( $>70 \%$ of the total score) and it was pre-defined awareness scoring.

Table 1 shows $23.9 \%, 34.9 \%, 28.4 \%, 10.1 \%$ and $2.8 \%$ respondent's age were $16-20,21-25,26-30,31-35$ and $36-40$ years respectively whereas lowest and highest age were 16 and 40 as well. Mean \pm SD age of respondents was $25.31 \pm 5.10$.

More than half (55\%) of the respondents completed primary level education and $31.2 \%$ was illiterate (Table 2).

Most of the respondents were housewife (Figure 1).

Table 3 shows half of respondents monthly family income had 4000-10000 BDT followed by 11000-17000 BDT among $43.1 \%$ 
whereas lowest and highest income were 4000 and 30000 BDT. Mean \pm SD income of respondents was $10958.71 \pm 4282.89$ (136.98 USD \pm 53.53 USD) per month.

Majority of respondents were Muslim (86\%) (Figure 2).

Distribution of nuclear and joint family were $68 \%$ and $32 \%$ (Figure 3).

Table 4 reveals most of the respondents (82.6\%) had good awareness on clinical presentation (discoloration and disfiguration of nail) of onychomycosis.

As like clinical presentation awareness on seek medical care was also good among $83.5 \%$ respondents (Table 5 ).

No statistical significant association was found between occupation, family type, education, income and awareness on onychomycosis (Table 6).

Table 1: Distribution of respondents by age $(n=109)$

\begin{tabular}{|c|c|c|}
\hline Age (years) & Number & Percentage \\
\hline $16-20$ & 26 & 23.9 \\
\hline $21-25$ & 38 & 34.9 \\
\hline $26-30$ & 31 & 28.4 \\
\hline $31-35$ & 11 & 10.1 \\
\hline $36-40$ & 3 & 2.8 \\
\hline Total & 109 & 100 \\
\hline Mean \pm SD & \multicolumn{2}{|c|}{$25.31 \pm 5.10$} \\
\hline
\end{tabular}

Table 2: Distribution of respondents by education $(n=109)$.

\begin{tabular}{|c|c|c|}
\hline Education & Number & Percentage \\
\hline Illiterate & 34 & 31.2 \\
\hline Primary & 60 & 55 \\
\hline SSC & 12 & 11 \\
\hline HSC & 2 & 1.8 \\
\hline Graduate & 1 & 0.9 \\
\hline Total & 109 & 100 \\
\hline
\end{tabular}

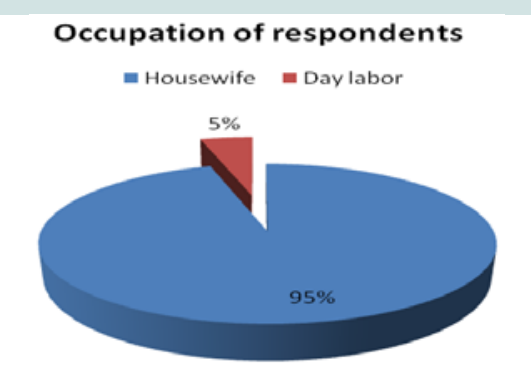

Figure 1: Distribution of respondents by occupation $(n=109)$.

Table 3: Monthly family income of respondents $(n=109)$.

\begin{tabular}{|c|c|c|}
\hline Income in BDT & Number & Percentage \\
\hline $4000-10000$ & 55 & 50.5 \\
\hline $11000-17000$ & 47 & 43.1 \\
\hline $18000-24000$ & 5 & 4.6 \\
\hline $25000-30000$ & 2 & 1.8 \\
\hline Total & 109 & 100 \\
\hline Mean \pm SD & \multicolumn{2}{|c|}{$10958.71 \pm 4282.89$} \\
\hline
\end{tabular}

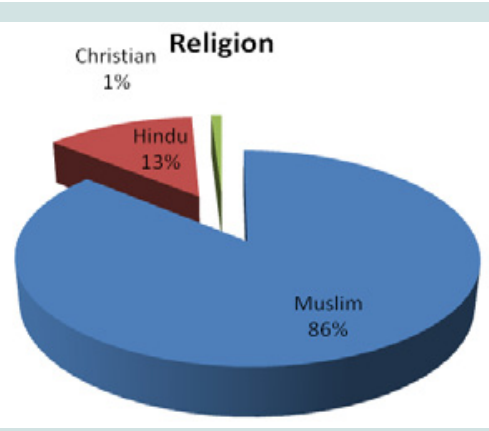

Figure 2: Religion of respondents $(n=109)$

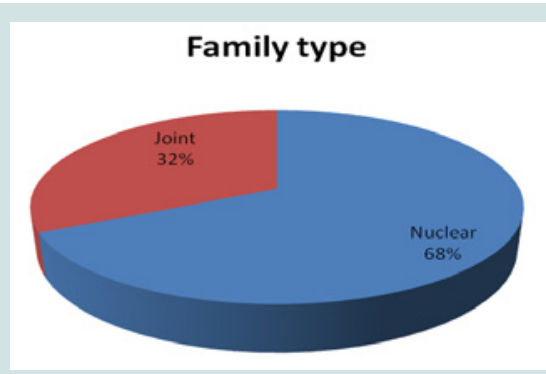

Figure 3: Type of family $(n=109)$.

Table 4: Distribution of respondents by awareness on clinical presentation of onychomycosis.

\begin{tabular}{|c|c|c|}
\hline Category of awareness & Number & Percentage \\
\hline Poor awareness (<50\%) & 2 & 1.8 \\
\hline Moderate awareness (50\%-70\%) & 17 & 15.6 \\
\hline Good awareness (>70\%) & 90 & 82.6 \\
\hline Total & 109 & 100 \\
\hline
\end{tabular}

Table 5: Distribution of respondents by awareness on seek medical care.

\begin{tabular}{|c|c|c|}
\hline Category of awareness & Number & Percentage \\
\hline Poor awareness (<50\%) & 2 & 1.8 \\
\hline Moderate awareness (50\%-70\%) & 16 & 14.7 \\
\hline Good awareness (>70\%) & 91 & 83.5 \\
\hline Total & 109 & 100 \\
\hline
\end{tabular}

Table 6: Association between variable of interest and awareness on onychomycosis.

\begin{tabular}{|c|c|c|c|c|c|}
\hline \multirow{3}{*}{ Variables } & \multicolumn{2}{|c|}{ Awareness on onychomycosis } & \multirow{3}{*}{ Total } & \multirow{3}{*}{$\boldsymbol{x}^{2}$} & \multirow{3}{*}{$\mathrm{p}$ value } \\
\hline & Poor awareness & Good awareness & & & \\
\hline & $\mathbf{N}$ & $\mathbf{N}$ & & & \\
\hline \multicolumn{6}{|l|}{ Occupation } \\
\hline Housewife & 18 & 86 & 104 & \multirow[t]{2}{*}{0.024} & \multirow[t]{2}{*}{0.624} \\
\hline Day labor & 1 & 4 & 5 & & \\
\hline \multicolumn{6}{|l|}{ Family Type } \\
\hline Nuclear & 16 & 58 & 74 & \multirow{2}{*}{2.812} & \multirow{2}{*}{0.076} \\
\hline Joint & 3 & 32 & 35 & & \\
\hline \multicolumn{6}{|l|}{ Income } \\
\hline$<17000$ & 18 & 84 & 102 & \multirow[t]{2}{*}{0.051} & \multirow[t]{2}{*}{0.821} \\
\hline$\geq 17000$ & 1 & 6 & 7 & & \\
\hline \multicolumn{6}{|l|}{ Education } \\
\hline$<S S C$ & 19 & 87 & 106 & \multirow[t]{2}{*}{0.651} & \multirow[t]{2}{*}{0.42} \\
\hline$\geq S S C$ & 0 & 3 & & & \\
\hline
\end{tabular}


Results were expressed as frequency percentage, $\varkappa^{2}$ test was performed and $\mathrm{p}<0.05$ was level of significance.

\section{Discussion}

The importance of onychomycosis is often underestimated. Far more than being a simple cosmetic problem, infected nails serves as a chronic reservoir of infection which can give rise to repeated mycotic infections of the skin [5]. Onychomycosis occurs worldwide and appears to be a variable entity presenting in different forms in different parts of the world with every country and every region of country having its own characteristics of presentation [6]. Several studies indicated that not all patients affected by onychomycosis seek medical assistance but present study found most of the patients were aware about seek medical help but we don't know about severity of the disease [7-9]. A study was done in India stated that the commonest age group affected in onychomycosis in their study was 21-30 $(25,24.6 \%)$ years followed by $31-40(35,20.2 \%)$ years which was almost similar with my study. Age of the most respondents was between 20 to 30 years whereas mean age was 25 years [5]. A similar high incidence among 2130 years age group was reported by Reddy et al. [9]. In contrast Mercantini et al. Velez et al. reported a higher prevalence among adults over the age of 50 years $[10,11]$. Increased participation in physical activity increased exposure to wet work, shoe wearing habit among this age group and early marriage leading to new household responsibilities could be some of the contributing factors for the increased prevalence in the 21-30 years age group. This study found that most of the respondents had good awareness on clinical presentation (discoloration and disfiguration of nail) of onychomycosis and as like clinical presentation awareness on seek medical care was also good among $83.5 \%$ respondents and no significant association was found with socioeconomic condition. Actually it was cross cut survey. As it is a recurrent disease so awareness on onychomycosis will bring great help for the patients.
No similar study was found to compare its similarity and dissimilarity and it is a great limitation. Awareness is a qualitative matter, so it is very difficult to measure ones awareness level by a set of questions.

\section{Conclusion}

Overall awareness level on different area of onychomycosis among patients was quite acceptable. Large scale study can be conducted to explore more accurate and precise result.

\section{References}

1. Scher RK (1996) Onychomycosis: A significant medical disorder. J Am Acad Dermatol 35: S2-S5.

2. Doyle JJ, Boyko WL, Ryu S, Gause D (2000) Onychomycosis among diabetic patients: Prevalence and impact of nonfungal foot infections. The American Diabetes Association $60^{\text {th }}$ Scientific Sessions. pp. 9-13.

3. Elewski BE (1997) Bacterial infection in a patient with onychomycosis. J Am Acad Dermatol 37: 493-494.

4. Rich P (1996) Special patient populations: Onychomycosis in the diabetic patient. J Am Acad Dermatol 35: S10-S12.

5. Jesudanam TM, Rao GR, Lakshmi DJ, Kumari GR (2002) Onychomycosis: A significant medical problem. Indian J Dermatol Venereol Leprol 68: 326-329.

6. Eleweski BE (1996) Diagnostic techniques for confirming onychomycosis. J Am Acad Dermatol 35: S6-S9.

7. Evans EV (1996) Onychomycosis: Challenges for diagnosis: In: Proceedings of the 2nd International Symposium on Onychomycosis. Florence, Italy 1995 Gardiner Caldwell Communications Ltd. 710.

8. Roberts DT (1992) Prevalence of dermatophyte onychomycosis in the United Kingdom: Results of an omnibus survey. Br J Dermatol 126: 23-27.

9. Ramesh V, Singh R, Reddy BS, Kumari S (1982) Clinico-mycological study of onychomycosis. Indian J Dermatol Venereal Leprol 48: 145-150.

10. Velez A, Linares MJ, Fernandez-Roldan JC, Casal M (1997) Study of onychomycosis in Cordoba, Spain: Prevailing fungi and pattern of infection. Mycopathologia 137: 1-8.

11. Lopes JO, Alves SH, Mari CR, Oliveira LT, Brum LM, et al. (1999) A tenyear survey of onychomycosis in the central region of the Rio Grande do Sul, Brazil. Rev Inst Med Trolp Sao Paulo 41: 147-149 